\title{
Hıristiyan Arap Yuhanna ed-Dımeşkî’nin İslam Eleştirisi $^{*}$
}

\section{Recep Aydoğmuş**}

Atıf/@: Aydoğmuş, Recep, Hıristiyan Arap Yuhanna ed-Dımeşkî'nin İslam Eleştirisi, Artuklu Akademi, 2020/7 (1), 147-176.

Öz: Hıristiyanların İslam'a karşı polemik yapmaları erken dönemlerden itibaren başlamıştır. İslam'a karşı polemik yapan öncü Hıristiyan teologlardan biri de Emevîler döneminde (661-750) yaşayan Yuhanna ed-Dımeşkî́dir (675-749). Hıristiyan teolojisini savunmak amaciyla pek çok eser kaleme almış olan Yuhanna'nın en önemli eserlerinden biri Bilginin Kaynağı'dır. Bu eser üç bölümden oluşmaktadır. İslam'a ilişkin görüşleri eserin Sapkınlara Dair isimli ikinci bölümü içerisinde yer alan İsmaîl̂lerin Sapkınlı̆̆ başlığı altında yer almaktadır. Onun Kuran, Hz. Muhammed, İslam inanç esasları ve İslam' da yer alan bazı pratiklere ilişkin düşünceleri burada yer alır. Bu makaledeki temel amaç Yuhanna'nın İslam'a yönelik eleştiri ve değerlendirmelerini sistematik olarak ve derinlemesine ele almaktır. Makalede deskriptif bir yöntem kullanılacak olup konu ile ilgili birincil ve ikincil kaynaklar kullanılacaktır.

Anahtar Kelimeler: Polemik, Yuhanna ed-Dımeşkî, İslam, Kuran, Hz. Muhammed

\section{Christian Arab John of Damascus's Critique of Islam}

Citation/@: Aydoğmuş, Recep, Christian Arab John of Damascus's Critique of Islam, Artuklu Akademi, 2020/7 (1),147-176.

\begin{abstract}
The polemics of Christians against Islam started from early ages. One of the leading Christian theologians who started the polemics against Islam is John of Damascus (675-749) who lived in the Umayyad period. One of the most important works of John, who wrote many works to defend Christian theology, is The Fount of Knowledge. This work consists of three parts. His views on Islam are included in the second part of the work, On Heresies, under the heading of the Heresy of Ishmaelites. His thoughts on the Qur'an, Muhammad, the principles of
\end{abstract}

Bu makale, İstanbul Üniversitesi Sosyal Bilimler Enstitüsü bünyesinde tarafımızca hazırlanan Yuhanna edDımeşkî’nin Eserlerinde İslam ve Müslümanlar başlıklı yüksek lisans tezinden faydalanılarak hazırlanmıştır.

* Ankara Üniversitesi Sosyal Bilimler Enstitüsü Felsefe ve Din Bilimleri Dinler Tarihi Doktora Öğrencisi, MEB Din Kültürü ve Ahlak Bilgisi Öğretmeni, recep1994.43@gmail.com. 
Islamic beliefs and some practices in Islam are included here. The main purpose in this article is to address John's criticism and evaluation of Islam systematically and in-depth. A descriptive method will be used in the article and primary and secondary sources will be used.

Keywords: Polemic, John of Damascus, Islam, the Qur'ann, Muhuammad

\section{Giriş}

İslam fetihleri ile Sâsânî (224-651) ve Bizans'in (330-1453) elinde bulunan toprakların Müslümanların yönetimine geçmesiyle birlikte, fethedilen bölgelerde yaşayan diğer din mensuplarından İslam dinini benimseyenler olmuştur. Özellikle Bizans'in kontrolünde olan Suriye bölgesinin el değiştirmesi sonucu bölgede yaşayan pek çok Hıristiyan, İslam dinini benimsemiş ve bu durum Hıristiyan din adamlarını tedirgin etmiştir. ${ }^{1}$ Hem bu din değiştirmelerin önünü kesmek hem de İslam'a karşı Hıristiyanlığı savunmak maksadıyla bazı iddialar öne sürülmüş ve polemikler yapılmıştır. Bu konuda öncü olan Hıristiyan teologlardan biri de şüphesiz Yuhanna ed-Dımeşkî́dir.

Sekizinci yüzyılda Şam’da yaşayan Yuhanna ed-Dımeşkî (675-749),

Emevî (661-750) iktidarında mali bürokraside görev almış, daha sonra siyasi ve dinî sebeplerden ötürü işinden ayrılıp manastıra çekilmiş, kendini ilmî çalışmalara ve asketik yaşama adamıştır. Burada çoğunluğu Hıristiyan teolojisi ile ilgili olan pek çok eser kaleme almıştır. Ayrıca heretik olarak kabul ettiği dinlere de değinmiştir. Bilginin Kaynağı (The Fount of Knowledge) başlıklı eserinin Sapkınlara Dair isimli ikinci bölümünde İslam'ı da heretik gruplardan biri olarak sunmuştur.

Mezkûr kitabın ikinci bölümünde yer alan İsmaîlîlerin Sapkınlı̆̆g başlıklı İslam'a ilişkin kısım kısa olmasına rağmen İslam'ın pek çok alanı ile ilgili malumat içermektedir. Eserde, Arapların kökeni, cahiliye Arap inançları, Kuran-1 Kerim, Hz. Muhammed, İslam inanç esasları ve muamelata dair bazı hususlar, İslam'ın Hıristiyanlık ve Hz. İsa'ya bakışı gibi pek çok konu yer almaktadır. Bu yönüyle onun söz konusu eseri İslam'ı bütüncül ele almaya çalışan ilk apolojik çalışmalardan biri olma vasfını taşımaktadır.

Yuhanna ile ilişkili olarak farklı dillerde yapılmış pek çok kitap ve makale bulunmaktadır. Onun İslam hakkındaki düşüncelerini ele alan en

Bu konu ile ilgili olarak bkz. Zafer Duygu, "Zuknin Manastırı Süryani Kroniği (775) Özelinde İslam İdaresi Altındaki Hıristiyanlarda "Din Değiştirme" Meselesi", Milel ve Nihal İnanç, Kültür ve Mitoloji Araştırmaları Dergisi, 10/2 (2013): 173-201. 
önemli eserlerden biri ise Daniel J. Sahas'in John of Damascus on Islam The "Heresy of The Ishmaelites"2 isimli eseridir. Türkiye' de de Yuhanna ile ilişkili yapılan tez ve makaleler bulunmaktadir. Mustafa Göregen'in Hiristiyan Teolojisinde Yahya Dımeşki'nin Yeri ve Önemi , Leyla Hanecioğlu'nun Yuhanna ed-Dımeşki'nin İslam ve Hıristiyanlık Arasındaki İlişkideki Yerí, isimli yüksek lisans tezleri ve İsmail Taşpınar'ın Doğu'nun Son Kilise Babası Yuhanna edDımaşki (649-749) ve İslam ${ }^{5}$ başlıklı makalesi zikredilebilir. Bahsi geçen iki tezden ilki Yuhanna'yı daha ziyade Hıristiyanlık açısından ele almakta iken ikinci tez onun İslam'a yönelik düşüncelerine değinmekle beraber daha çok kelamî bir perspektifle yaklaşmaktadır. Taşpınar ise makalesinde onun İslam'a ilişkin görüşlerine odaklanmaktadır. Bu makalede ise Yuhanna'nın sadece İslam'a yönelik görüşleri ele alınmakta, kelamî bir perspektif tercih edilmemektedir. Ayrıca onun Hıristiyanlık ile ilgili düşüncelerine değinilmemektedir. Güncel kaynaklardan da istifade edilmesi makaleyi diğer çalışmalardan ayırmaktadır. Makalede istifade edeceğimiz temel kaynak Yuhanna'nın Bilginin Kaynă̆ı isimli eserinin çevirisinin yer aldı̆̆ Saint John of Damascus Writings 6 başliklı eserdir. Ayrıca Yuhanna hakkında yapılmış olan ikincil kaynaklardan da faydalanilacaktır.

Makale üç ana bölümden oluşmaktadır. İlk bölümde Yuhanna'yı daha iyi tanımak adına hayatı ve ilgili eseri hakkında bilgi verilecektir. İkinci bölümde İslam, Müslümanlar ve Hz. Muhammed'e yönelik düşünce ve iddialarına değinilecektir. Üçüncü bölümde ise Kuran-1 Kerim ve İslam inanç esaslarına ilişkin bilgisi ele alınacaktır.

Daniel J. Sahas, John of Damascus on Islam The "Heresy of The Ishmaelites", (Leiden: Brill Publisher, 1972)

Mustafa Göregen, "Hıristiyan Teolojisinde Yahya Dımeşki'nin Yeri ve Önemi", Basılmamış Yüksek Lisans Tezi, Marmara Üniversitesi SBE, İstanbul, 1995.

4 Leyla Hanecioğlu, "Yuhanna ed-Dımeşki'nin İslam ve Hıristiyanlık Arasındaki İlişkideki Yeri", Basılmamış Yüksek Lisans Tezi, Ankara Üniversitesi SBE, Ankara, 2002.

5 İsmail Taşpınar, "Doğu'nun Son Kilise Babası Yuhanna ed-Dımaşki (649-749) ve İslam", Marmara Üniversitesi İlahiyat Fakültesi Dergisi, 21/2 (2001).

6 Frederic H. Chase (çev.), Saint John of Damascus Writings, The Father of The Church, ed. Roy Joseph Deferrari, C. XXXVII, (New York, 1958). Makalede, bu eserde yer alan On Heresies, On Orthodox Faith başliklı bölüm adlarını kullanacağız. 


\section{Yuhanna'nın Hayatı ve İslam'a İlişkin Eseri}

\section{A. Hayatı}

Yuhanna ed-Dimeşkî ya da tam ismiyle Mansûr b. Sercûn et-Tağlîbî́nin hayatına ilişkin bilgiler kesinlik arz etmemektedir. Doğumu genel olarak 675 olarak kabul edilmektedir. ${ }^{7}$ Onun sağlam bir eğitim aldığı babası Sercûn'un ona Sicilyalı Kosmas'ı hoca olarak tuttuğu ve Kosmas'tan Grekçe, felsefe, hendese, mûsikî ve astronomi gibi pozitif ilimleri tahsil ettiği belirtilmektedir. ${ }^{8}$

Yuhanna'nın, Emevîler döneminde babası ve dedesi gibi 9 mali bürokraside görev aldığı ifade edilmektedir. ${ }^{10} \mathrm{O}$, bazı siyasî ve dinî sebeplerden ötürü malî bürokrasideki görevini terk etmiş daha sonra Mar Saba Manastırı' na yerleşmiş ve eserlerini burada kaleme almıştır. Ölene kadar manastırda kaldığı belirtilen Yuhanna'nın ölüm tarihi ve cenazesinin nereye gömüldüğü hususu net değildir. Genellikle Siméon Vailhé'nin tespit ettiği 749 onun ölüm yılı kabul görmektedir. ${ }^{11}$ Onun ölünce Mar Saba Manastırı'na gömüldüğü iddia edilmektedir. ${ }^{12}$

\section{B. Bilginin Kaynă̆ı ve İsmaîlîlerin Sapkınlığı}

Bilginin Kaynağı isimli eseri Yuhanna'nın en önemli çalışması kabul edilmektedir. Bu eseri İngilizceye çeviren Frederic Chase eserin önemini şöyle vurgulamaktadir:

“Bilginin Kaynağı, kendi zamanına kadarki Grek patristik literatürü kapsamlı ve net şekilde sentezleyen en önemli eserlerden biridir. O hem Doğu'da hem Batı'da yazılan ilk

7 bkz. Berthold Altaner, Patrology, çev. Hilda C. Graef, (New York, 1961), 640. Philip Khuri Hitti, History of Syria, (New York: Macmillan Education, 1951), 49. Nasrallah Yusuf ise 655-660 arasında olduğunu düşünmektedir. bkz. Yusuf Nasrallah, Mansûr b. Sercûn el-Ma'rûf bil'Kıddîs Yuhanna ed- Dımeşkî, (Beyrut: Menşurat el-Mektebe el-Bulsiyye, 1991), 81.

8 Theophanes, The Chronicle, çev. Harry Turtledove, (Philadelphia: University of Pennsylvania Press, 1982), 47. Chase, Saint John of Damascus Writings, XXXVII, VI. Daniel J. Sahas, John of Damascus on Islam The "Heresy of The Ishmaelites", (Leiden: Brill Publisher, 1972), 39-41.

9 bkz. Eutychius, Annales, Scriptores Arabici Textus Series Tertia-Tomus, ed. ve çev. Louis Cheikho, (Beirut, 1909), VII, 15. Theophanes, The Chronicle, 64, 80. Philip Khuri Hitti, History of The Arabs From The Earliest Time to The Present (New York: Macmillan Education, 1970), 246.

10 bkz. Nasrallah, Mansûr b. Sercûn, 95. Sahas, John of Damascus, 42-43.

11 İsmail Taşpınar, "Doğu'nun Son Kilise Babası Yuhanna ed-Dımaşki (649-749) ve İslam”, Marmara Üniversitesi İlahiyat Fakültesi Dergisi, 21/ 2 (2001); 29; Bu tarihin kabul edilme sebepleri için bkz. Sahas, John of Damascus, 47; Taşpınar, "Yuhannaed-Dımaşki", 29.

12 bkz. Nasrallah, Mansûr b. Sercûn, 160-161. Chase, Writings, XIII. Sahas, John of Damascus, 47. 
summa teolojidir. ${ }^{13}$ Doğu'da ortaya çıkan ve teolojik öneme sahip olan son eserdir."14

Üç bölümden oluşan bu eserin ilk bölümü felsefi bahislerle ilgili olup bu bölüm ile müellif, teolojisine felsefî bir alt yapı hazırlar. ${ }^{15}$ Eserin ikinci bölümünü ise heretik kabul ettiği gruplara ayırmıştır. Sapkınlara Dair isimli bu bölümde İslam da heretik olarak kabul edilmektedir. Üçüncü bölümde ise Ortodoks Hıristiyanlığının esaslarını açıklamaya çalışmaktadır. Yuhanna bu eseri ile teoloji, felsefe, kendi zamanında heretik kabul edilen gruplar ve kendisinden önce yaşamış olan kilise babalarının görüşlerine dair bol miktarda bilgi aktarmaktadır. 16

Yukarıda belirtildiği gibi onun İsmaîlîlerin Sapkınlığı başlıklı yazısı Bilginin Kaynağı isimli eserinin ikinci bölümü olan Sapkınlara Dair içerisinde yer almaktadır. En eski versiyonun yer aldığı Jacques Paul Migne'ın Patrologia Graeca isimli çalışmasında Sapkınlara Dair 103 heretik gruptan oluşmakta, Kotter'ın çalışmasında ise 100 heretik grup bulunmaktadır. Migne'ın çalışmasında İsmaîlîlerin Sapkınlı̆̆ı 101. kısım iken, Kotter'in çalışmasında 100. kısımdır. ${ }^{17}$

Onun İslam'a ilişkin mezkûr eserinde cahiliye Araplarının inançları, Kuran, Hz. Muhammed, İslam inanç ve esaslarına yönelik düşünce ve değerlendirmeleri yer almaktadır. Aşağıda onun bu hususlardaki değerlendirmeleri ele alınacaktır.

\section{Arapların Kökeni, İslam Öncesi İnanç, İslam, Müslümanlar ve Hz. Muhammed Hakkındaki Görüşleri}

\section{A. Müslüman Arapların Kökenine Dair Görüşleri}

Yuhanna'nın İsmaîlîlerin Sapkınlığı eserinde "Müslüman veya Arap" ismini kullanmadığını belirtmemiz gerekmektedir. O Müslüman veya Araplar kelimeleri yerine "İsmâ̂lîler, Hâcerîler ve Sarasinler" ifadelerini kullanmaktadır:

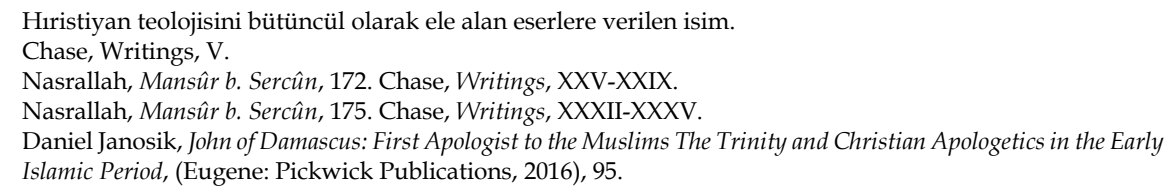


Onlar İbrahim ve Hacer'in soyundan gelmektedir. Bundan dolayı onlar Hâcerîler ve İsmaîlîler olarak isimlendirilmektedirler. Onlar ayrıca Sarasinler olarak da isimlendirilmektedir. Bu, Hacer'in meleğe "Sare beni mahrum bırakarak gönderdi" demesinden dolayı "Sare tarafından mahrum bırakılmışlar" anlamına gelmektedir. ${ }^{18}$

Buradan da anlaşılacağı üzere, Müslüman Arapların kökenine yönelik üç kavram söz konusudur. Bunlar "İsmâ̂lîler, Hâcerîler ve Sarasinler" ifadeleridir. Onun Müslüman Araplar için bu isimleri kullanması muhtemelen kendi döneminin Araplara bakış açısını yansıtmaktadır. Nitekim Suriye Hıristiyanlarının Araplar için İsmaîlîler, Hâcerîler ve Sarasinler isimlerini kullandıkları bilinmektedir. ${ }^{19}$ Yuhanna da kendi döneminde buna uyarak Araplar için aynı isimleri kullanmış olmalıdır.

Onun Müslümanlar veya Araplar yerine bu isimleri kullanmasının bir diğer sebebi ise, İslam'ı, Yahudi-Hıristiyan geleneğiyle bağlantılı olarak düşünmesi olabilir. Nitekim İsmail, Hacer ve Sare hem Yahudi-Hıristiyanlıkta hem de İslam'da yer alan ortak şahıslardır. Yuhanna'nın Müslüman ismini tercih etmemesi onun İslam'a ilişkin kanaati de olabilir. Daha sonra detaylıca değineceğimiz üzere o İslam'ı bir din olarak görmemektedir. İslam, her ne kadar Kur'an'da kendisini evrensel bir din olarak tanımlasa da ona göre İslam, Emevî dönemi Araplarının benimsediği sapkın bir gelenektir. Araplar ise İsmail'in soyundan gelmektedir ${ }^{20}$ Dolayısıyla onun açısında Müslümanlar yerine İsmâilîler demek daha doğru olacaktır.

Yuhanna'nın Araplar için Hacerîler ismini kullanması daha önce de zikredildiği gibi dönemin bakışını yansıtmaktadır. Fakat Müslümanların Hacerîler olarak isimlendirilmesi tahkir amacı taşımaktadır. Bunun sebebi Hacer'in, Sare'nin kölesi olmasıdır. Hacerîler ifadesi ile Müslümanlara köle oldukları hususu hatırlatılmak istenmektedir. Nitekim onun "Sarasinler" kelimesinin kökenine dair Eski Ahit'ten ${ }^{21}$ faydalanarak yaptığ1 mezkûr yorumdan bu durum anlaşılmaktadir.

Yuhanna'nın Araplar için kullandı̆̆ı bir diğer isim Sarasinlerdir. Sarasin kelimesinin ne anlama geldiği ve Müslümanlar için niçin kullanıldığı

\footnotetext{
18 John of Damascus: On Heresies, Saint John of Damascus Writings, çev. Frederic H. Chase, The Father of The Church, ed. Roy Joseph Deferrari, (New York, 1958), XXXVII, 153.

19 Jonathan P. Berkey, The Formation of Islam: Religion and Society in the Near East, 600- 1800, (Cambridge University Press, 2003), 74.

20 Andrew Louth, Saint John of Damascene, (Oxford University Press, 2002), 78.

21 Tekvin 16: 8; 17:15.
} 
hususunda ortak bir kanaat bulunmamaktadır. O bu konuda bir açıklama yapmaktadır. Ona göre Sarasin kelimesi Eski Ahit'te ${ }^{22}$ ifade edilen ve Hacer'e atfedilen bir sözden dolayı kullanılmaktadır. ${ }^{23} \mathrm{Bu}$ yorumu ile o Hacer'in soyundan gelen Arapların köle olduğunu ima etmektedir.

Mes'ûdî, et-Tenbîh ve'l-İşrâf isimli eserinde Bizans imparatoru 1. Nikiforos'un (802-811) Arap kelimesinin kullanılmasını yasakladığını, bunun yerine "Sarras Xenous" (ساراقينوس ) kelimesinin kullanılmasını emrettiğini aktarmaktadır. Mes'ûdî bu kelimenin "Sare' nin kölesi" anlamında olduğunu ve İmparatorun bu ifade ile Hacer ve İsmail soyundan gelen Araplar1 aşağılamak istediğini zikretmektedir. Ayrıca kendi dönemine kadar Müslümanların bu şekilde isimlendirildiğini de eklemektedir. ${ }^{24}$ Kelimeye bu anlam verildiği takdirde "Sarasin" ile ilgili Yuhanna'nın açıklaması doğru gözükmektedir.

\section{B. İslam Öncesi Arap İnançlarına Dair Görüşleri}

İslam öncesi dönem hakkında bazı ifadeleri bulunan Yuhanna bu konuda şunları ifade etmektedir:

Onlar (Araplar) putperestlerdi ve Sabah Yıldızı ile kendi dillerinde "büyük" anlamina gelen "Kabar" diye isimlendirdikleri Afrodit'e ibadet ederlerdi. ${ }^{25}$

İslam öncesi dönemde Arapların pagan olduğu bilinmektedir. Onun bu konuda bilgisiz olduğunu düşünmek mümkün değildir. Arapların kökenini İbrahim ve İsmail ile ilişkilendiren Yuhanna'nın daha sonra onların putperest olduklarını belirterek belki de ataları monoteist olan Arapların pagan olmalarını yadırgamaktadır. Monoteist bir gelenekten olmalarına rağmen putperest olmaları aynı zamanda onların sapkın karakterlerini de ortaya koymaktadır. Bu ise onun açısından normal bir durum değildir. Nitekim o, sapkın olarak tanımlasa bile $\mathrm{Hz}$. Muhammed'in onları paganizmden monoteizme döndürdüğünü belirtmektedir. ${ }^{26} \mathrm{Bu}$ konuda menfî bir yorumda bulunmaması onun bu durumdan memnun olduğu anlamında düşünülebilir.

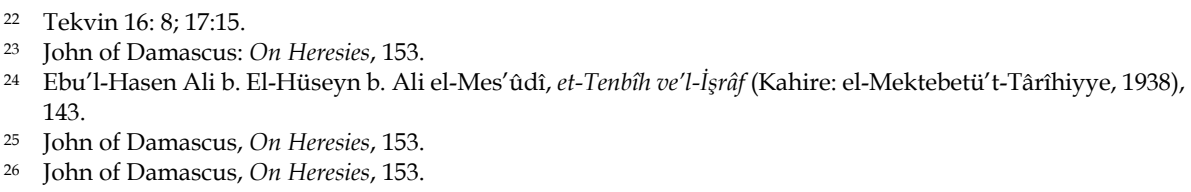


Kuzey ve Güney Arabistan'da göksel varlıklara Tanrılık atfedildiği de bilinmektedir. Nitekim Yemen kökenli Himyer kabilesinin Güneş ve Ay gibi gök cisimlerine Tanrılık atfettikleri rivayet edilmektedir. ${ }^{27}$ Hicaz bölgesinde ise göksel cisimlere ne zamandan beri kutsallık atfedildiği bilinmemekle beraber Kur'an'1 Kerim'deki “Gece ve gündüz, Güneş ve Ay Allah'ın ayetlerindendir. Güneş'e ve Ay'a secde etmeyin. Eğer sadece onun kulu iseniz onları yaratan Allah'a secde edin" 28 ayeti Hicaz Arapları arasında göksel cisimlere tanrısallık atfedildiği gerçeğine bir gönderme olabilir. Dolayısıyla Yuhanna'nın ima ettiği gibi Arapların göksel varlıklara kutsiyet atfettikleri yorumunu yapmamız mümkün görünmektedir.

Arapların Afrodit'e taptıklarına yönelik kaynaklarda bir açıklama bulunmamakla beraber Yuhanna belki de Afrodit ile Güney Arapları arasında kutsallik atfedilen Athar'1 ima etmektedir. Nitekim Athar'1n hem sabah hem de akşam olmak üzere iki görünümü olduğu, sabah ve akşam yıldızı olarak isimlendirildiği de ifade edilmektedir. ${ }^{29}$ Öte yandan Arapların panteonunda yer alan Uzzâ'nın Afrodit'e tekabül ettiği belirtilmektedir. ${ }^{30}$ Uzzâ'nın Afrodit'e tekabül ettiği ve bölgeye göre farklı bir isim aldığı kabul edilse bile Arapların Afrodit'e taptığına yönelik net bir bilgi bulunmamaktadır. O muhtemelen bu konudaki bilgisini dönemin Bizans kaynaklarından almış olmalıdır. ${ }^{31}$

Yuhanna, Arapların Afrodit'i "büyük" anlamına gelen "Kabar" şeklinde isimlendirdiklerini iddia etmektedir. İbnü'1 Kelbî Arapların Kâbe'yi tavaf ederken aşağıdaki şekilde telbiye getirdiklerini aktarmaktadır:

\section{"Lât hakkı için, Uzzâ hakkı için! Üçüncüleri Menât hakkı için! Onlar ulu turnalardır, Onların şefaatine ümit bağlanabilir!”32}

Bu rivayette görüldüğü üzere Uzzâ ulu ve şefaati ümit edilebilir bir put olarak kabul edilmektedir. Şayet Afrodit ile Uzzâ'nın kastedildiği kabul edilirse bu durumda Yuhanna'nın, Arapların Afrodit'i “büyük/ulu” olarak

Seyyid Mahmud Şükri El-Âlûsî, Bulûğu'l-Ereb fî Ma'rifeti Ahvâli'l-Arab (Misır: el-Mektebetu'1 Ehliyye, 1924), 237-239.

28 Fussilet, 41/37.

29 Sahas, John of Damascus, 72 ve 2. dipnot.

30 Buna göre Atargatis, İştar, İsis, Afrodit, Venüs ve Uzzâ aynı tanrıçalar olup bölgeye göre farklı isimler almışlardır. bkz. H. J. W. Drijvers, Cults and Beliefs at Edessa, (Leiden: Brill Publisher, 1980), 185. Şevket Yavuz, "Uzzâ", DİA, https://islamansiklopedisi.org.tr/uzza (Erişim tarihi 19.10.2019), XXXXII, 268.

31 Robert G. Hoyland, Seeing Islam as Others Saw It a Survey and Evaluation of Christian, Jewish and Zoroastrian Writings on Early Islam, (New Jersey: The Darwin Press, 1997), 489.

32 İbnu'l-Kelbî, Kitâbu'l-Esnâm, çev. Beyza Düşüngen Bilgin, (Ankara: Ankara Okulu Yayınları, 2016), 55. 
nitelediklerine yönelik iddiaları kabul edilebilir. Fakat "Kabar" kelimelerinin ne anlama geldiği ise bilinmemektedir. Bu kelimeler belki de "kebîr/büyük" kelimesinin Grekçe bir telaffuzundan ibarettir.

\section{C. İslam'a İlişkin Düşünceleri}

Yuhanna'nın İslam hakkındaki görüşlerine geçmeden önce kısaca onun İslami bilgi kaynaklarına değinmekte yarar vardır. Onun İslam'a dair ilk kaynağı kuşkusuz Kur'an'1 Kerim'dir. O, eserinde her ne kadar Kur'an ismini zikretmese de Kur'an'dan bazı alıntılar yapmaktadır. Ayrıca bazı sure isimlerini (Nisâ, Mâide, Bakara) vermektedir.

Yuhanna, Hz. Muhammed'in hadislerine herhangi bir atıfta bulunmamaktadır. Daha doğrusu onun bakışında Kur'an ve hadis ayrımı söz konusu değildir. O, İslam'a dair verdiği bilgileri Hz. Muhammed'in sözü olarak vermektedir. Bu bilgiler arasında hem ayetler hem de hadis olarak değerlendirebileceğimiz ifadeler bulunmaktadır. Söz gelimi o Hz. Muhammed'in, Müslüman erkek ve kadınlara sünnet olmalarını emrettiğini belirtmektedir. 33 İslam'daki sünnet uygulamasının kaynağının Kur'an'1 Kerim olmadığı malumdur. Bu konudaki bilgi kaynağı hadislerdir. O muhtemelen Hz. Muhammed'in bu konudaki emrini duymuş olmalıdır. Belki de o, Müslümanlar arasında fiilî olarak uygulanan bu pratikten hareketle bu sözleri sarfetmektedir.

Onun İslam hakkındaki bilgilerinin bir diğer kaynağı Müslümanlar arasındaki pratikler olmalıdır. Evlilik ve ticarette şahitlik gibi hususlara değinen 34 Yuhanna'nın bu konudaki bilgisi muhtemelen bu pratiklere yakînen şahitlik etmesinden gelmektedir. Paul Khoury'ye göre onun İslam ile ilgili verdiği bilgilere bakıldığında bunların ya Kitab-1 Mukaddes'e ya Kur'an'a ya da yaşadığı çevredeki Müslümanlardan edindiği bilgilere dayandı̆̆ı görülecektir. ${ }^{35}$ Robert Hoyland ise onun bazı bilgilere anlatılar yoluyla ulaşmış olabileceğini söylemektedir. Bu konuda daha sonra ele alacağımız "dişi deve” kıssası ve Hacerü'l-Esved ile ilgili bilgileri örnek verir. Ona göre Yuhanna'nın bu konulardaki bilgi kaynağı Kur'an'dan çok Müslümanlar arasındaki anlatılardır. O, Yuhanna'nın bazı bilgilere ise Bizans

35 Paul Khoury, "Jean Damascène et l'Islam", Proche-Orient Chrétien 7 (1957), 51, Akt. Taşpınar, "Yuhanna edDımaşki", 33 . 
kaynaklarından ulaşmış olabileceğini söylemektedir. Bu konuda daha önce değindiğimiz Arapların Afrodit'e taptığı iddiasını örnek vermektedir. ${ }^{36}$

Yuhanna, eserinin hiçbir yerinde "İslam" ismine atıfta bulunmamaktadır. Bunun yerine "İsmaîlîlerin hurafesi" ve "sapkınlık" demeyi tercih etmektedir.

Ayrıca günümüzde hâlâ hüküm süren ve insanları yanlışa sürükleyen, Antichrist'in (Mesih karşıtı) öncüleri olan İsmaîlîlerin hurafesi vardır. ${ }^{37}$

Ona göre ana akımdan kopan her oluşum heretiktir. O İslam'1 da Hıristiyanlıktan neşet etmiş bir akım olarak tahayyül ettiğinden ve İslam Kitab-1 Mukaddes'e aykırı doktrinler içerdiğinden İslam din değil heretik bir akımdir. 38

Yuhanna, İslam' 1 heretik bir akım olarak değerlendirse de, onun heretik kabul ettiği diğer din ve ekollere nazaran İslam'a daha çok yer vermesi ve takipçilerinde İslam'a yönelik negatif bir imaj çizmeye çalışması aslında onun İslam'ı önemsediğini ve Hıristiyanlık için bir tehlike olarak gördüğünü düşündürmektedir. 39

Öte yandan o İslam'ın kaynağına yönelik bazı açıklamalarda da bulunmaktadır. Bu hususta şunları zikretmektedir:

Aralarından Mahmed isminde sahte bir peygamber ortaya çıktı. $\mathrm{Bu}$ adam tesadüfen Eski ve Yeni Ahit'ten edindiği bilgiler ile ayrıca Aryüsçü bir keşiş ile görüşmesinden sonra kendi sapkınlığının temelini attı. ${ }^{40}$

Yuhanna İslam'ın kaynağına yönelik olarak temelde iki şey ileri sürmektedir. Bunlardan biri Kuran'ın kaynağının Eski ve Yeni Ahit olduğu iddiasıdır. Mekke ve çevresinde Hıristiyan varlığı bilinmektedir. Hz. Muhammed'in Hiristiyan ve Yahudilerle irtibatta olduğu da bir vakıadır. Onun ilk vahiy tecrübesinin ardından Eski ve Yeni Ahit'i bilen Varaka b.

\footnotetext{
6 Hoyland, Seeing Islam, 489.

37 John of Damascus, On Heresies, 153.

Janosik, John of Damascus, 99.

39 Janosik, John of Damascus, 216. Örneğin, Epikürizm, Pisagorizm, Platonizm gibi bazı bazı felsefi ideolojiler ve Yahudilik ve Sâmirîlik gibi bazı din ve mezheplere kısaca, çoğu zaman bir paragraf ile değinmektedir. İslam'a ilişkin görüşleri ise bunlara nispeten daha uzun olup yaklaşık 8 sayfa kadar yer almaktadır. Bkz. John of Damascus, On Heresies, 111-160.

40 John of Damascus, On Heresies, 153.
} 
Nevfel ile görüştüğü kabul edilmektedir. Öte yandan Mekke'de başka Hıristiyanların yaşadığı da bilinmektedir. Belki de o, bu gibi bilgilerden hareketle İslam'ın kaynağını Eski ve Yeni Ahit olarak zikretmiş olabilir.

İslam'ın kaynağına ilişkin bir diğer iddia ise Hz. Muhammed'in Aryüsçü bir rahip ile iletişime geçtikten sonra İslam' ${ }_{1}$ oluşturduğu yönündedir. $\mathrm{O}$, Aryüsçü rahibin kimliğine ilişkin bir bilgi vermemektedir. Aryüsçü rahip ile muhtemelen Rahip Bahîrâ'yı kastediyor olmalıdır. İslam tarihi kaynaklarında Rahip Bahira kıssası yer almakla birlikte onun Aryüsçü olduğuna yönelik tespit edebildiğimiz kadarıyla herhangi bir ifade yer almamaktadır. ${ }^{41}$ Öte yandan bu kıssanın güvenilirliği de tartışma konusudur. ${ }^{42}$

\section{Müslümanlar Hakkındaki Görüşleri}

Yuhanna eserinde Müslüman ismini zikretmemektedir. Daha önce zikredildiği gibi İsmailî, Hacerî ve Sarasin ifadelerini kullanmaktadır. Müslümanları kastederek şu nitelemeyi yapmaktadır:

Ayrıca günümüzde hâlâ hüküm süren ve insanları yanlışa sürükleyen, Antichrist'in öncüleri olan İsmailîlerin hurafesi vardir. ${ }^{43}$

Yuhanna "insanları yanlışa sürükleyen" ifadesiyle Müslümanların doğru yoldan sapan ve başka insanları da yoldan saptıran kişiler olduğunu kastetmektedir. Müslümanlara yönelik bu bakış açısı müşrikler tarafından da dile getirildiği bilinmektedir. Nitekim onlar "Müminleri gördüklerinde, "Bunlar gerçekten doğru yoldan sapmış kimseler!" derlerdi." 44 Dolayısıyla Müslümanlara yönelik bu bakış açısının ondan önce olduğunu varsaymamız mümkündür. Müslümanların, yanlışa sürüklediği kişiler ile kastedilen muhtemelen Hıristiyanlardır. İslam idaresi altında pek çok kişinin din değiştirdiği bilinen bir husustur. İslam dinini benimseyenler arasında Hıristiyanlar da mevcuttur. Bu durum Yuhanna açısından kabul edilemezdir.

\footnotetext{
41 Hıristiyan yazarlar onun kimliğine ilişkin açıklamalar yapmaktadırlar. Abdü'1 Mesîh b. İshak el-Kindî onun adın Sergius olarak vermekte ve onun Nestûrî bir keşiş olduğunu söylemektedir. Migne'ın P. G'da anonim bir metin onu Yakûbî olarak, Euthymius Zygabenus ise onu Aryüsçü olarak vermektedir. Bkz. Sahas, John of Damascus, s. 74

42 Bu hususta bkz. Ahmet Erçetin, "Rivayetler ve Farklı Yorumlar Işı̆̆ında Rahip Bahîrâ Olayı", (Yayımlanmamış Yüksek Lisans Tezi, Selçuk Üniversitesi SBE, Konya 2008)

43 John of Damascus, On Heresies, 153.

44 el-Mutaffifîn, 83/32.
} 
Dolayısıyla ona göre Müslümanlar insanları doğru yoldan saptıran kimselerdir.

Yuhanna'nın Müslümanlara yönelik bir diğer ithamı "Antichrist" ifadesidir. "Mesîh karşıtı" veya İslamî literatürde "deccal" 45 olarak isimlendirilen Kitab-1 Mukaddes kaynaklı bu ifadeyi o Müslümanlar için kullanmaktadır. Onun Müslümanları niçin Antichrist olarak nitelediğini anlamak adına onun bu ifadeye yüklediği anlama değinmemiz gerekmektedir. O bu hususta şunları söylemektedir:

Antichrist' in kesin olarak geleceği bilinmelidir. Bu nedenle Tanrı oğlunun enkarne olup geldiğini, mükemmel bir tanrı, Tanrı olmakla beraber aynı zamanda mükemmel bir insan olduğunu kabul etmeyen herkes Antichrist'tir. ${ }^{46}$

Onun bu açıklamaları esas alındığı takdirde Müslümanları niçin Antichrist olarak nitelendirdiği netlik kazanmaktadır. Buna göre İsa'nın enkarne ve hem Tanrı hem de beşer olduğunu kabul etmeyen herkes Antichrist olarak nitelenmeyi hak etmektedir. Müslümanlar Hz. İsa'nın bir peygamber ve mahlûk olduğunu kabul etmekte ve onun Tanrı olduğunu reddetmektedirler. Dolayısıyla Yuhanna'nın nazarında onlar da Antichrist olmaktadirlar.

Yuhanna' nın Müslümanlara yönelik bir diğer ithamı onların putperest oldukları şeklindedir. Müslümanların Hıristiyanları müşrik ve putperest olarak nitelemelerine bir tepki olarak ileri sürdüğü anlaşılan bu iddiaya göre Müslümanlar İslam öncesi inancın bir devamı olarak Kâbe'de bulunan taşa kutsiyet atfetmekte ve ona tapmaktadırlar. Nitekim o bu konuda şunları söylemektedir:

Nasıl oluyor da siz kendinizi Kâbe'deki taşa sürtüyor, onu öpüyor ve kucakliyorsunuz? ${ }^{47}$...Bahsettikleri bu kaya "Kabar" diye isimlendirdikleri ve kendisine ibadet ettikleri Afrodit'in

\footnotetext{
45 bkz. Kürşat Demirci, "Deccâl”, DİA, https://islamansiklopedisi.org.tr/deccal\#1 (Erişim tarihi, 19.10.2019), IX, 67-69.

46 John of Damascus, Orthodox Faith, Saint John of Damascus Writings, çev. Frederic H. Chase, The Father of The Church, ed. Roy Joseph Deferrari, (New York, 1958), XXXVII, 398-399.

47 John of Damascus, On Heresies, 156.
} 
başıdır. Günümüzde bile üzerindeki oyma izleri dikkatli bakanlar tarafından görülebilir. ${ }^{48}$

"Kâbe'deki taş" ifadesi ile kastedilen muhtemelen "Hacerü'1Esved/siyah taş" olmalıdır. Fakat onun iddia ettiği gibi bu taşın "Kabar" olarak isimlendirildiğine yönelik bir rivayet bulunmamaktadır. Sahas, bu kelimenin Müslümanların Kâbe'yi tavaf ederken tekbir ve tehlil getiriyor olmalarından hareketle "Allah ekber" ifadesinden esinlenerek Yuhanna tarafından verilmiş olabileceğini söylemektedir. ${ }^{49}$ Fakat bu konuda kesin bir bilgi bulunmamaktadır. Sahas'a göre Hacerü'l Esved üzerinde var olduğu ileri sürülen izler uzun süreli dokunma sonucu olmuş olmalıdır. Ayrıca İslam öncesi dönemde bu taşa kutsallık atfedilmesi, Yuhanna'nın onu Afrodit'in başı olduğu kanaatine sevk etmiş olmalıdır. ${ }^{50}$ Benzer bir düşünceden hareketle bazı araştırmacıların da Hacerü'1 Esved'in Afrodit'in başı olduğunu ileri sürdükleri belirtilmektedir. ${ }^{51}$ Fakat ne Afrodit'in kendisine ne de Hacerü'l Esved'in Afrodit'in başı olduğuna yönelik kaynaklarda bir bilgi bulunmaktadir.

Yuhanna'nın Hacerü'l Esved ile ilgili söylediklerinden İslam ile cahiliye arasında bir bağ kurmaya çalıştı̆̆ını ve İslamî dönemde Müslümanların putperest tavırları sürdürdüklerini ima etmesini anlamamız mümkündür. İslam öncesi dönemde Arapların bu taşa kutsiyet atfettikleri hususu bilinmektedir. Hz. İbrahim'in tavafın başlangıcını belirlemek için koyduğu söylenen bu taşın ${ }^{52}$ hac menasiklerinin vazgeçilmez bir unsuru olduğu bilinmektedir. Aynı kutsiyetin İslamî dönemde de devam ettirildiği malumdur. Dolayısıyla o Müslümanların İslam öncesi putperest uygulamalardan kurtulamadiklarını ima etmektedir. Bu durum, onu Müslümanları putperest olarak nitelemeye sevk etmiş olmalıdır.

Yuhanna Müslümanların Hacerü'l Esved'i niçin kutsadıkları hususunda da bir takım açıklamalar yapmaktadır:

Onlardan bazıları İbrahim'in Hacer ile onun üzerinde ilişkiye girdiğini, diğer bazıları ise İshak'ı kurban etmek için gittiğinde

\footnotetext{
John of Damascus, On Heresies, 156-157.

Sahas, John of Damascus, 87.

50 Sahas, John of Damascus, 87-88. Arent Jan Wensick, “Ka'ba”, A Handbook of Early Muhammadan Tradition Alphabetically Arranged, (Leiden: Brill Publisher, 1927), 120.

51 Cevâd Ali, el-Mufassal fî Târîhi'l-Arab Kable'l-İslâm, (Câmiatu Bağdad, 1993), IV, 436-437.

52 Muhammed b. İshak, Siyer, haz. Muhammed Hamidullah, çev. Sezai Özel, (İstanbul: Akabe Yayınları, 1988), 148.
} 
deveyi ona bağladığını söylerler. Biz onlara şu şekilde cevap veriyoruz: "Kitab-1 Mukaddes dağın ormanlık ve ağaçlar olduğunu, İbrahim' in, kurban etmek için odun kestiğini ve İshak üzerine serdiğini ve eşekleri geride, iki genç adama teslim ettiğini söyler. Niçin saçma sapan konuşuyorsunuz? Çünkü bu yerde ne sık ağaçlar ne de eşeklerin geçeceği bir yer vardır. Onlar utanıorlar fakat yine de bu taşın İbrahim'in olduğunu iddia ediyorlar. Ve biz şöyle diyoruz: Aptalca söylediğiniz gibi bırakın İbrahim'in olsun. Sırf İbrahim bir kadın ile onun üzerinde ilişkiye girdiği veya bir deveyi ona bağladığı için siz onu öpmeye utanmiyorsunuz. ${ }^{53}$

$\mathrm{Bu}$ ifadeleri ciddiye almak mümkün olmamakla beraber onun Müslümanları niçin putperest olarak nitelediğini göstermesi açısından önemlidir. $\mathrm{O}$ bu ifadeleri ile sapkın bir Müslüman imajı çizmeye çalışmaktadır. Yuhanna, politeizmden monoteizme dönüşümde İslam'ın etkisinin farkında olmakla beraber özellikle Hacerü'l Esved ile ilgili Müslümanların bazı hassasiyetlerini dillendirerek İslam'ın cahiliye dönemi putperest yapısından beslendiğini ima etmektedir. Onun tahayyülünde Müslümanların Hacerü'1 Esved ile ilgili tavırları İslam'ın orijinal bir din olmadığının, putperest gelenekleri devam ettiren sapkın bir gelenek olduğunun göstergelerindendir. İslam öncesi dönemden kalma bazı uygulamaların İslam'da sürdürülmesi muhtemelen onu böyle düşünmeye sevk etmiş olmalıdır. Nitekim İslam'ın cahiliyeden kalma her şeyi yasaklamadığı, İslam inanç ve öğretileri ile çelişmeyen kimi uygulamaları aynen devam ettirdiği, bazılarını düzelttiği bazılarını da tamamen kaldırdığı bilinmektedir. Dolayısıyla Müslümanların Hacerü'1 Esved'e ilişkin tavrını bu açıdan ele almak gerekmektedir.

\section{E. Hz. Muhammed'e İlişkin Görüşleri}

Yuhanna eserinde Hz. Muhammed'in ismini zikretmekle beraber Muhammed yerine "Mamed" 54 demeyi tercih etmektedir. Onun Muhammed yerine Mamed ifadesini kullanması muhtemelen Grekçe telaffuz ile ilgilidir.

Hz. Muhammed'e yönelik ifadeleri incelendiğinde, peygamberimizin hayatına dair bir bilgi vermediği görülmektedir. İlgili eserinde $\mathrm{Hz}$. Muhammed'in ne işle meşgul olduğu, Mekke'deki mücadelesi, Medine

53 John of Damascus, On Heresies, 156.

54 John of Damascus, On Heresies, 153. 
dönemi faaliyetleri, Müslüman toplumun oluşumundaki rolü, savaşları gibi hususlara değinilmemektedir. Bu durum Yuhanna'nın Hz. Muhammed'in hayatı hakkında yeterli ve doğru bir bilgiye sahip olmadığını düşündürmektedir. ${ }^{55} \mathrm{O}, \mathrm{Hz}$. Muhammed ile ilgili eleştiri konusu olduğunu düşündüğü hususlara odaklanmaktadır. Hz. Muhammed'in sahtekâr, yalanc1, hileci ve şehvetine düşkün biri olduğu gibi iddialar ön plana çıkmaktadır. O, Hz. Muhammed ile ilgili olarak şu açıklamaları yapmaktadır:

O zamandan günümüze aralarından Mamed isminde sahte bir peygamber ortaya çıtı. Bu adam tesadüfen Eski ve Yeni Ahit'ten edindiği bilgiler ile ayrıca Aryan bir keşiş ile görüşmesinden sonra kendi sapkınlığının temelini attı. Ondan sonra kurnazca, insanlara gösteriş yaparak kendini merhametli gösterip kendisi hakkında iyi bir izlenim verip kendisine gökten güvenilir bir kitap indirildiğini bildirdi. ${ }^{56}$

Aslında Hz. Muhammed'in şahsına yönelik hakaretler Yuhanna'dan çok öncesine dayanmaktadır. Kur'an'ı Kerim, Mekke müşriklerinin Hz. Muhammed için ileri sürdükleri bazı iddiaları bize aktarmaktadır. Kâhin, şair, mecnun, büyücü ve yalancı gibi kötü sıfatlar $\mathrm{Hz}$. Muhammed için kullanılmakta; fakat bu iddialar Allah tarafından reddedilmektedir. ${ }^{57}$

Yuhanna'ya göre Hz. Muhammed Eski ve Yeni Ahit'ten elde ettiği bilgileri ve Aryüsçü bir rahipten edindiği bilgileri kendisine nispet ederek insanları aldatmıştır. O muhtemelen Hz. Muhammed'i Kitab-1 Mukaddes'te geleceği haber verilen yalancı peygamberler ile özdeşleştirmiş olmalıdır. ${ }^{58} \mathrm{O}$, Hz. Muhammed'in İslam öncesi dönemde "el-Emin" 59 olarak nitelendiği gerçeğine gölge düşürme gayreti içerisinde olup, Hz. Muhammed'in dindar görünerek insanlara gösteriş yaptı̆̆ını ve onları aldattığını ifade etmekte, onun güvenilir sıfatını göz ardı etmektedir.

Hz. Muhammed'in şehvetine düşkün bir insan olduğu hususu da Yuhanna tarafından vurgulanmakta olan bir diğer önemli meseledir. Onun bu konudaki temel çıkış noktası Zeyd olayıdır. Hz. Muhammed' in evlatlığı ve yakın arkadaşı olan Zeyd'in karısı Zeynep b. Cahş'ı boşaması ve $\mathrm{Hz}$. Muhammed'in Zeynep ile evlenmesi şeklinde özetleyebileceğimiz bu olaydan

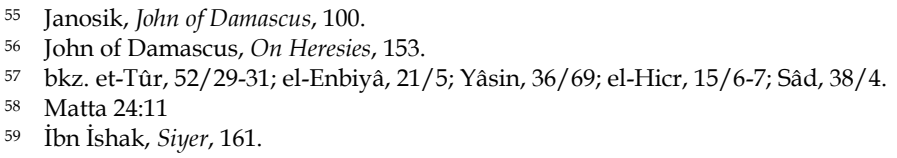


hareketle Yuhanna Hz. Muhammed'in şehvetperest ve kadınlara değer vermeyen bir kimse olduğunu işlemeye çalışmaktadır. Onun bu konudaki ifadeleri şu şekildedir:

O ayrıca kişinin istediği kadını boşayabileceğini, aynı şekilde istediği kadını da alabileceğini söyler. Muhammed'in Zeyd adında bir arkadaşı vardı. Bu adamın, Muhammed'in kendisine âşık olduğu çok güzel bir karısı vardı. Bir ara beraber otururlarken Muhammed dedi ki: Tanrı bana senin karını almamı emretti. Diğeri cevapladı: Sen bir öndersin. Tanrının sana dediğini yap ve karımı al. Daha doğrusu -hikâyeyi baştan söyleyecek olursak-O, ona dedi ki: Tanrı bana senin karını boşamanı emretti. Ve o, onu boşadı. Birkaç gün sonra dedi ki: Şimdi ise Tanrı bana onu kendime almamı emretti. Onu kendisine alıp, onunla zina ettikten sonra ise bunu şerî bir kural haline getirdi. 60

Ahzab Suresi'nde de söz konusu edilen Zeyd kıssasının amacı Kuran-1 Kerim'e göre cahiliyede yerleşmiş olan yanlış bir uygulamayı ortadan kaldırmaktır. Buna göre kişi kendi evlatlığının boşamış olduğu kadın ile 162 evlenemezdi; fakat Kuran bu uygulamanın yanlış olduğunu göstermek amacıyla Zeyd kıssasını zikretmektedir. Yuhanna ise Hz. Muhammed'in Zeyd'in karısından hoşlandığını ve ona âşık olduğu için Zeyd'in karısını boşadığını iddia etmektedir. O Zeyd olayını Hz. Muhammed'in kadınlara düşkünlüğü bağlamında ele almakta ve bu olaya binaen Hz. Muhammed'in boşanmayı meşrulaştırdığını ifade etmektedir. $\mathrm{O}$ ayrıca bu ifadeleri ile İslam'ın şehveti ön plana çıkaran heretik bir akım olduğunu göstermeye çalışmaktadır. ${ }^{61}$

Hz. Muhammed'in Zeynep ile evlenip ilişkiye girmesi Yuhanna açısından zina olarak değerlendirilmektedir. Onun bu konudaki referansı Kitab-1 Mukaddes olmalıdır. Nitekim Yeni Ahit'te boşanan kadın ile evlenen kişinin zina etmiş olacağı söylenmektedir:

60 John of Damascus, On Heresies, 157.

61 Janosik, John of Damascus, 107. Benzer ifadeler İslam tarihi kaynaklarında da yer almaktadır. bkz. İbn İshak, Siyer, 321. 
Ben size şunu söyleyeyim, karısını fuhuştan başka bir nedenle boşayıp başkasıyla evlenen, zina etmiş olur. Boşanan kadınla evlenen de zina etmiş olur. ${ }^{62}$

O, Hz. Muhammed'in Zeyd'ten boşanan Zeynep ile evlendiğini söylemektedir. Dolayısıyla bu onun nazarında zina olarak telakki edilmektedir.

Yuhanna Hz. Muhammed'in niçin peygamber olamayacağına yönelik olarak bazı argümanlar ileri sürmektedir. Bu konu ile ilgili iki temel vurgusu vardır. Bunlardan biri Hz. Muhammed'in peygamberliğine kimsenin şahitlik etmediği hususu bir diğeri ise onun geçmiş peygamberler ve kutsal kitaplar tarafından müjdelenmediği şeklindedir. Şahitlik konusunda şunları ifade etmektedir:

Şahit olmadan bir kadın ile evlenemiyor, bir mülkü satın alamıyor ve sahip olamiyorsunuz. Şahit olmadan ne bir eşek ne de bir yük hayvanına sahip olamıyorsunuz. Şahit olmadan ne bir kadın ne de bir eşeğe sahip olamıyorsunuz; fakat elinizde tuttuğunuz kutsal yazılarınızı ve imanınızı şahitlerle ispatlamadan kabul ediyorsunuz. $\mathrm{Bu}$, onun size indirdiği şey hakkında herhangi bir kaynaktan bir garantiye sahip olmamasından, o gelmeden önce ona şahitlik edecek herhangi bilinen birinin olmamasındandır. Aksine o uykudayken onu ald1. ${ }^{63}$

Ona göre en basit konularda dahi şahit isteyen Kuran-1 Kerim Hz. Muhammed'in peygamberliği konusunda ise şahit getirmeyi şart koşmamakta ve bu durum onun peygamberliğine şüphe düşürmektedir. $\mathrm{O}$ ayrıca şahitlik konusunda kendi kutsal kitabından bazı referanslar vermekte ve görüşlerini desteklemektedir:

Musa, Sina Dağı'nda, tüm insanların gözü önünde, bulut, ateş, karanlık ve rüzgârın arasından görünen Tanrı'dan Tevrat'1 almıştır... Biz, "Nasıl oluyor da sizin peygamberiniz aynı yolla, kanıt taşıyan başka şeylerle gelmedi? Nasıl oluyor da Tanrı sizin başvurduğunuz kitabı bu adama -insanlar bakarken, dumanlı dağlar üstünde Musa' ya kanunu (Tora) verdiği gibi-kesin olsun diye

Matta 19: 9; Markos 10:11-12.

John of Damascus, On Heresies, 155. 
sizin önünüzde vermedi?" Diye sorduğumuzda onlar "Tanrı dilediğini yapar" derler. ${ }^{64}$

Yuhanna nazarında bir kişinin peygamber olarak kabul edilebilmesi için onun apaçık mucizeler ile desteklenmesi gerekmektedir. Somut ve herkesin görebileceği şekilde Tanrı'dan vahiy aldığını ispat edemeyen kişi peygamber değildir. Hz. Musa herkesin önünde Tanrı ile görüşmüş ve peygamberliğini ispat etmiş; ${ }^{65}$ fakat $\mathrm{Hz}$. Muhammed herkesin görüp şahitlik edebileceği şekilde, mucizevi bir şekilde peygamberliğini ispat edememektedir. Öyleyse o peygamber olmamalıdır.

Hz. Muhammed'in peygamberliğini kanitlayacak mucize ve somut delilinin olmadığını ifade eden Yuhanna başka bir argüman daha sunmaktadır. Argümanın merkezinde yer alan kişi ise İsa Mesîh'tir. O, İsa'nın önceki peygamber ve kutsal kitaplar tarafından haber verilip müjdelendiğini ileri sürmekte ve $\mathrm{Hz}$. Muhammed'in tebşir edilmediğini iddia etmektedir. Bu konuda şunları söylemektedir:

Ayrıca Musa'dan itibaren tüm peygamberlerin Mesîh'in geleceğini, Mesîh' in Tanrı olduğunu (Tanrı'nın oğlu olarak enkarne olduğunu), haça gerileceğini, öleceğini, tekrar dirileceğini ve ölü ve dirileri nasıl yargılayacağını haber verdiğini söylüyoruz... Fakat biz, “Tanrı'nın ona (Hz. Muhammed) Kitab'1 verdiğine kim şahit olmuş? Ayrıca hangi peygamber onun ortaya çıkacağını haber vermiştir?" Diye sorduğumuzda onlar sessizliğe gömülürler. ${ }^{66}$

Yuhanna, İsa'nın kendisinden önceki peygamberler ve kutsal kitaplar tarafından müjdelendiğini; fakat Hz. Muhammed'in peygamber olarak geleceğinin haber verilmediğini iddia etmektedir. Kur'an'1 Kerim ise Allah' ın peygamberlerden $\mathrm{Hz}$. Muhammed geldiğinde iman edeceklerine dair söz aldığını, son peygamberin geleceğinin Tevrat ve İncil'de yazılı olduğunu ve ehli kitap âlimlerinin bunu bildiği ifade etmektedir. ${ }^{67}$ Ayrıca Hz. İsa'nın Hz. Muhammed'i müjdelediği Kur'an'da açıkça belirtilmektedir. ${ }^{6}$

\footnotetext{
4 John of Damascus, On Heresies, 154.

Çıkış 19:16-22.

John of Damascus, On Heresies, 154.

Âl-i İmrân, 3/92; el-A'râf, 7/157.

6 es-Saff, $61 / 6$.
} 


\section{Kuran-1 Kerim ve İslam İnanç Esaslarına İlişkin Değerlendirmeleri}

\section{A. Kuran-1 Kerim'e Yönelik Değerlendirmeleri}

Yuhanna'nin eserinde "Kur'an" ismine herhangi bir atıf bulunmamaktadır. Bunun yerine "yazı (grafe-scripture) ve kitap (biblos, book)" ifadeleri kullanılmaktadır. ${ }^{69}$ Onun "Kur'an" ismini niçin zikretmediği bilinmemektedir. Muhtemelen bu onun kendi tercihi olmalıdır. Nitekim benzer ifadeler kendi kutsal kitabı için de söz konusu edilmektedir. ${ }^{70}$ Kur'an $^{\prime}$ ismini zikretmemesinin sebebi bu ismi telaffuz etmeye değer görmemesiyle ilişkili de olabilir. Nitekim Kur'an'1 Kerim için “gülünç kompozisyon” ve "aptalca" gibi aşağılayıcı ifadelere yer vermesi bu hususu destekler mahiyettedir. ${ }^{71} \mathrm{O}$, "kitap" ifadesi ile hem bütün olarak Kur'an'1 Kerim'i hem de sureleri kastetmektedir. Ayrıca o Nisâ, Mâide ve Bakara gibi bazı sure adlarını açıkça zikretmekte ve içeriklerine dair bilgi vermektedir. ${ }^{72}$ Onun bazı surelerin adını açıkça zikretmesi sure isimlerinin en azından sekizinci yüzyılın ilk çeyreğinde Hıristiyan bilginler tarafından bilindiğini göstermektedir.

Yuhanna, Kur'an'ın kaynağına ve oluşumuna dair bazı iddialar ileri sürerek ilahi bir hitap olmasına karşı çıkmaktadır. Daha önce de değinildiği gibi $\mathrm{O}, \mathrm{Hz}$. Muhammed'in Eski ve Yeni Ahit'ten bazı bilgiler elde ettiğini ve Aryüsçü bir rahip ile irtibata geçtikten sonra kendisine gökten bir kitap indirildiğini iddia etmektedir. Ona göre Kur'an, ilahi bir kitap olmadı̆̆ı gibi, içeriğinde gülünç ifadelerin yer aldığ 1 bir derlemedir. ${ }^{73}$ Esasen Kuran'1 $\mathrm{Hz}$. Muhammed'e birilerinin öğrettiği iddiası Kur'an'ın nazil olduğu sürece dayanmaktadır. ${ }^{74}$ Dolayısıyla o bu iddialarda bulunan ilk kişi değildir.

Yuhanna'nın Kur'an'ın tamamına ulaşabilmiş olacağını söylemek mümkün değildir. Kur'an üzerine görüş ve yorumları dikkate alındığında onun Kur'an'ın ancak bir kısmından haberdar olduğu anlaşılmaktadır. O sadece birkaç surenin isimlerini vermekte ve bu surelerden alıntılar yapmaktadır. Bu durum değindiği konularla ilgili Kur'an ayetlerinden haberdar olabileceğini göstermektedir. Yehuda Nevo, onun bazı Arap

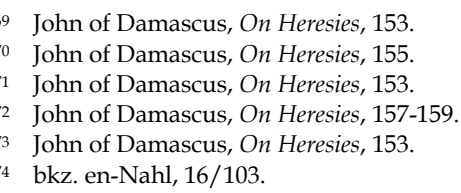


geleneklerine ve Kur'an'ın bir kısmına aşina olduğunu ifade etmektedir. Zira ona göre, Yuhanna, Kur'an'dan tek bir kitap olarak bahsetmemekte, bunun yerine farklı kitaplar olduğunu ifade etmektedir. Bu durum onun Kur'an ile ilgili bazı hususlardan haberdar olduğunu göstermektedir. ${ }^{75}$ Hoyland, İslam'ın İsa'ya bakışı ve Kur'an'ı Kerim konusunda onun iyi bir bilgiye sahip olduğunu iddia ederken, ${ }^{76}$ Andrew Louth, onun Hz. Muhammed'e inen vahyi ve Kur'an'ı iyi bildiğini, ayrıca bazı sureler ve içeriklerinden de haberdar olduğunu belirtmektedir. ${ }^{77}$ Meyendorff ise onun bilgisinin sadece referans verdiği ayetlerden ibaret ve ikinci elden olduğunu ifade etmektedir. ${ }^{78}$

Yuhanna' nın alıntı yaptığı ayetlerin hata ve eksikler içermesi, onun bu ayetleri Müslümanlardan sözlü olarak duymuş olabileceğini veya kendi yorumuyla ve aklında kaldığı kadarıyla aktardığını ya da maksatlı olarak değiştirmiş olabileceğini düşündürmektedir. Ayrıca Emevîler döneminde Hıristiyanların Kuran'ı öğrenmelerinin ve okumalarının yasaklandığına dair rivayetler de mevcuttur. ${ }^{79} \mathrm{Bu}$ durum onun Kuran ayetlerini ilk elden almadığını destekler mahiyettedir.

Yuhanna bazı sure isimleri zikretmektedir. Bunlar Nisa, Maide, Bakara ve Tanrı'nın Devesi sureleridir. Nisa Suresi ile ilgili olarak şunları ifade etmektedir:

Örneğin Kadın hakkında yazdığı bir kitap vardır. Orada açıkça şeri bir hüküm olarak; mümkünse dört kadın alınabileceğini ve bu dört kadının dışında eğer bakılabilecekse bin cariye alabileceğini söylemektedir. ${ }^{80}$

O, Hz. Muhammed'in Nisâ Suresi'ni kadınlar hakkında yazdığını belirtmektedir. Surenin genel olarak kadınlara ilişkin hükümler içermesi onun bu değerlendirmeyi yapmasına sebebiyet vermiş olmalıdır. Onun, surenin tamamından haberdar olduğunu söylemek mümkün değildir. Nitekim o sadece surenin ilk kısımlarından referans vermekte, geri kalan kısımlara bir atıfta bulunmamaktadır. Onun bu ifadeleri Nisa Suresi'nin 3.

\footnotetext{
Yehuda Nevo, Judith Koren, Crossroads to Islam: The Origins of the Arab Religion and the Arab State, (Amherst, 2003), 238.

76 Hoyland, Seeing Islam, 488.

77 Louth, Saint John of Damascene, 80.

78 John Meyendorff, Byzantine Theology Historical Trends and Doctrinal Themes, (New York: Fordham University Press, 1979), 51.

79 Bu hususta bkz. Mustafa Fayda, "eş-Şürûtü'l-Ömeriyye", DİA, https://islamansiklopedisi.org.tr/essurutul-omeriyye (Erişim tarihi, 19.10.2019), XXXIX, 273.

80 John of Damascus, On Heresies, 157.
} 
ayeti ile benzerlik göstermekte; fakat birebir aynı değildir. Her iki ifadede de kişinin dört kadın ile evlenebileceği belirtilmektedir. Fakat ayette kişinin bin cariye (kadın köle) alabileceğine yönelik bir açıklama bulunmamaktadır. Yuhanna'nın Nisâ suresinde özellikle poligamiye temas etmesi onun başka bir amaç taşıdığını göstermektedir. O Müslümanların şehvetine düşkün kimseler olduğunu ve diledikleri kadar kadın ile birlikte olabileceklerini ima etmektedir.

Onun isim zikrettiği bir diğer sure Mâide'dir. "Sofra" anlamına gelen bu sure ile ilgili olarak şunları zikretmektedir:

Aynı şekilde Sofra kitabında Muhammed, Mesih'in Tanrı'dan bir sofra istediğini ve kendisine verildiğini söyler. Çünkü onun dediğine göre Tanrı şöyle dedi: "Sana ve size bozulmayacak bir sofra verdim. ${ }^{81}$

Yuhanna'nın söz konusu ettiği olay Mâide Suresi 112-115. ayetlerde geçmektedir. $\mathrm{O}$, bu ayetlerin ana temasından haberdar olmakla beraber detaylarına girmemektedir. İsa'nın Allah'tan bir sofra talep ettiği hususu doğru olmakla beraber "Sana ve seninkilere hiç bozulmayacak bir sofra verdim" şeklindeki ifadesine ayetlerde rastlanmamaktadır.

Onun Mâide Suresi ile ilgili olarak sadece sofra mucizesine değinmesi onun asıl amacının Hıristiyanlık ve İsa ile ilgili anlatılar olduğunu düşündürmektedir. Ayrıca Hıristiyanlıktaki "Son Akşam Yemeği" ni andıran bir pasaj olduğunu düşünmesi onun bu ayetleri zikretmesinin bir diğer sebebi olabilir. Nitekim bazı Hıristiyan yazarlar da bu ayetlerde "Son Akşam Yemeği "ne işaret olduğunu düşünmektedir. ${ }^{82}$

Yuhanna'nın sure ismi belirtmeden yaptığı aşağıdaki açıklamaları da Maide Suresi 116-118. ayetlerde yer almaktadır:

Ey İsa! Sen mi: Tanrı'nın oğluyum ve Tanrı'yım, dedin?" Ve onun demesine göre, İsa şöyle cevap verdi: "Bana karşı merhametli ol Rabbim! Sen benim bunu söylemediğimi ve sana kul olmayı küçümsemediğimi daha iyi biliyorsun. Ancak, günahkâr insanlar, benim böyle bir açıklama yaptığımı yazdılar ve onlar, benim adıma

1 John of Damascus, On Heresies, 159.

82 bkz. Tor Andrae, Mohammed: The Man and His Faith, (Routledge, 2008), 39. 
yalan uydurup yanılgıya düştüler. Ve Tanrı ona cevap verip şöyle dedi: “Ben, senin bu sözü söylemediğini biliyorum. ${ }^{83}$

Yuhanna'nın ifadeleri onun Maide Suresi'ndeki ilgili ayetlerden haberdar olduğunu göstermektedir. Fakat onun verdiği bilgiler bu ayetlerle kıyaslandığında eksik ve hatalı kalmaktadır. İlgili ayetlerde Allah, sadece İsa' yı değil annesi Hz. Meryem'i de işin içine katmaktadır. O ise Hz. Meryem'i zikretmemekte bunun yerine Tanrı ve Tanrı oğlu ifadelerini kullanmaktadır. Ayette İsa'nın "Allah'a kul olmayı küçümsememesi" şeklinde bir ifade yoktur. Ayrıca Allah'ın "Ben, senin bu sözü söylemediğini biliyorum” şeklindeki bir cevabı da ayette yer almamaktadır.

Yuhanna'nın yukarıdaki ifadeleri bize onun Kur'an Sureleri ile ilgili olarak neleri önemsediğine dair fikir vermektedir. Hem gökten sofra indirilmesi hem de İsa'nın sorguya çekilmesine dair yaptığı açıklamalar bize onun Kur'an'1 Kerim'de daha çok İsa ve Hıristiyanlıkla ilgili konulara yöneldiğini göstermektedir.

Onun açıkça isim verdiği surelerden bir diğeri de Bakara Suresi'dir. O sure ile ilgili olarak şu açıklamayı yapmaktadır:

Aynı şekilde Sığır kitabında başka aptalca ve gülünç şeyler de söyler ki bunlar çokça olduğu için bunları geçebileceğimi düşünüyorum. ${ }^{84}$

Yuhanna'nın surenin içeriğine yönelik herhangi bir açıklama yapmamaktadır. Sure uzun ve farklı konuları ihtiva ettiğinden içeriğine değinme gereği duymamış olabilir. Fakat o Bakara Suresi'nde aptalca şeylerin olduğunu belirtmektedir. Onun "aptalca" ifadesini Bakara Suresi için özellikle kullanması muhtemelen ismi ile ilgili olmalıdır. O sureye bir hayvan isminin verilmesini komik ve gülünç bulmuş olmalıdır. Öte yandan Bakara Suresi'nin içeriğinde Yahudi ve Hiristiyanlara yönelik tenkitlerin bulunduğundan haberdar olduğu kabul edilirse, onun sureyi niçin aptalca olarak nitelemiş olabileceği daha anlaşılır hale gelmektedir.

Yuhanna'nin Bakara Suresi'nde yer alan bir ayetten haberdar olabileceği yorumunu yapmamız mümkündür. $\mathrm{O}$ yukarıdaki ifadelerinin haricinde başka bir yerde Nisâ Suresi bağlamında şu açıklamayı yapmaktadır:

John of Damascus, On Heresies, 154.

84 John of Damascus, On Heresies, 159. 
Aynı kitapta o şunun gibi kurallar söyler: Tanrının sana verdiği toprağ1 işle ve onu güzelleştir. Bunu yap ve bunu bu tarzda yap, onun söylediği müstehcen şeylerin tamamını tekrar etmemek için böyle söylüyoruz. ${ }^{85}$

Onun bu ifadeleri Bakara Suresi 223. Ayetini hatırlatmaktadır. Nitekim bu ayette "Kadınlar sizin ekinliğinizdir. Ekinliğinize dilediğiniz biçimde varın..." buyrulmaktadır. Bu benzerlik onun bu ayetten haberdar olabileceğini göstermektedir. Fakat o bu açıklamalarını Nisa Suresi bağlamında vererek hata etmektedir. Bu durum onun ayete ilk elden ulaşamamış olduğunu göstermektedir.

Yuhanna Kuran'da Tanrı'nın Devesi isminde başka bir surenin olduğunu da iddia etmektedir. Bu hususta şunları söylemektedir:

Tanrı'nın Devesi isminde bir kitap da vardır. Bu deve ile ilgili o: Tanrıdan gelen bir devenin olduğunu ve tüm nehri içtiğini ve yeterince yer kalmadığından dağların arasından geçemediğini söyler. Burada yaşayan insanların olduğunu, sırasıyla bir gün onların bir gün de devenin sudan içtiğini söyler. Dahası devenin su içerek onlara gıda verdiğini, su yerine onlara süt verdiğini, sonra kötü olan bu adamların ayaklanıp deveyi öldürdüklerini söyler. ${ }^{86}$

Kur'an'1 Kerim'de bu isimde müstakil bir sure bulunmamakla beraber Hz. Salih'e bir mucize olarak gönderilen bir dişi deveden söz edildiği bilinmektedir. Surelerin tek bir ismi olmadığı düşünüldüğünde bu ismin meşhur olmayan bir ad olabileceğini söylemek de mümkündür. ${ }^{87}$

Hans Küng, Yuhanna'nın dişi deve kıssası ile ilgili bir kısmını verdiğimiz anlatısını aptalca bulmakta ve onun kıssayı çarpıttığını belirtmektedir. ${ }^{88}$ Andrew Louth onun Kur'an'dan haberdar olduğunu; fakat deve kıssası ile ilgili bilgisinin yanlış olduğunu ifade etmektedir. ${ }^{89}$ Daniel Janosik ise Kur'an'ın dişi deve kıssasını ilahi adaleti vurgulamak için zikrettiğini, Yuhanna'nın ise kıssayı Müslümanların kitabında saçma şeylerin olduğunu kanıtlamak için ifade ettiğini ve kıssayı çarpıttığını vurgulamaktadır. O ayrica Yuhanna'nın bu anlatısının onun apolojisi

85 John of Damascus, On Heresies, 158.

86 John of Damascus, On Heresies, 158.

87 Taşpınar, "Yuhanna ed-Dimaşkî", 47, 116. Dipnot.

88 Hans Küng, Islam: Past, Present and Future, (OneWorld Publications, 2007), 8.

89 Louth, John of Damascene, 80. 
hakkında da fikir verdiğini, bu anlatısı ile onun İslam'ın zayıf yönünü gösterme çabası içerisinde olduğunu ifade etmektedir. ${ }^{90}$ Ayrıca bu kıssadan hareketle Kur'an'ın kanonizasyonuna yönelik bazı eleştiriler de yapılmaktadir..$^{91}$

\section{B. İslam İnanç Esasları ve İslam'da Yer Alan Bazı Pratiklere İlişkin Değerlendirmeleri}

Yuhanna satır aralarında hem İslam'ın Tanrı anlayışı ve cennet inancına hem de İslam da yer alan bazı muamelat esasları ve emir ve yasaklara da değinmektedir. Müslümanların tanrı anlayışına ilişkin şunları ifade etmektedir:

O yalnızca bir Tanrının olduğunu, her şeyi yarattığını, doğurmamış ve doğmamış olduğunu söylemektedir. ${ }^{92}$

Onun yukarıdaki ifadeleri ile Kur'an'ın özü olan tevhîdi anladığını hissettirmektedir. Ayrıca o tevhîdin Müslümanların temel inancı olduğunun farkında olup politeizm ve aynı şekilde şirk ile itham edilen Hıristiyanlığa bir reddiye olduğunun da farkındadır. ${ }^{93}$

Yuhanna Müslümanların ahiret inancına dair bilgi sahibi olduğunu da hissettirmektedir. Bu konu hakkında özel bir başlık açmamakta; fakat özellikle yukarıda değindiğimiz dişi deve kıssası bağlamında bazı hususlara değinmektedir:

Çünkü sizin dediğinize göre cennetinizde üç ırmağınız var. Bunlardan biri su biri şarap bir diğeri de süt ırmağıdır. Şayet öncünüz olan deve cennet dışında bir yerdeyse açıktır ki o açlık ve susuzluktan kurumuştur ya da başkaları onun sütünden faydalanıyordur. Dolayısıyla peygamberiniz Tanrı ile konuştu diye boşuna övünüyor; çünkü Tanrı ona devenin gizemini ifşa etmemiştir. Ama eğer o cennette ise hala su içmeye devam ediyordur ve siz zevk cennetinin ortasında susuzluktan dolayı kuruyacaksınız. Eğer deve tamamını içtiği için cennette su kalmazsa sizler şarap ırmağından şarap içmeyi arzulayacaksınız böylece saf şarabı içmekten kendinizden geçeceksiniz ve bu ağır sarhoşluğun

\footnotetext{
Janosik, John of Damascus, 214-215.

bkz. Nevo, Koren, Crossroads to Islam, 238. Janosik, John of Damascus, 205.

John of Damascus, On Heresies, 153.

Sahas, John of Damascus, 75.
} 
etkisinde kalacaksınız ve uykuya dalıp kalacaksınız. Ondan sonra uykudan dolayı ağır bir baş ağrısından ve şarap içmekten hasta düşmekten cennetin nimetlerini/zevklerini kaçıracaksınız. ${ }^{94}$

O, Müslümanların ahiret inancını ifade etmekten ziyade eleştiri ve tahkir etme niyetindedir. Bu bilgileri vererek özellikle dişi deve kıssasının saçmalığını ve bu kıssayı anlatan Hz. Muhammed'in peygamber

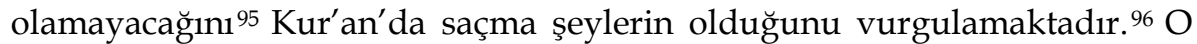
dişi deve kıssası bağlamında özellikle cennette yer alan su, şarap ve süt ırmaklarından bahsetmekte ve ayrıca cennet nimetlerine değinmektedir.

Yuhanna İslam'da helal ve haram kabul edilen bazı hususlara da değinmektedir. $\mathrm{O}$ bu hususta şunları ifade etmektedir:

O, erkek ve kadınların sünnet olmalarını şerî bir kural yaptı. Ayrıca şabata uymamalarını ve vaftiz olmamalarını emretti. O, Tevrat'ın haram kıldığı bazı şeyleri yemelerini emrederken bazı şeylerden de kaçınmalarını istedi. Üstelik şarap içmelerini kesinlikle yasakladı. ${ }^{97}$

O Yahudilik ve Hıristiyanlık açısından son derece önemli olan şabat ve vaftize değinerek İslam'ın, Hiristiyanlık ve Yahudilik'e reaksiyon gösterdiğini düşünmektedir. ${ }^{98}$

Yuhanna, Hz. Muhammed'in Tevrat'ta yer alan bazı şeyleri helal bazı şeyleri ise haram kıldığını ifade etmekte; fakat bu konuda detaya girmemektedir. O, Hz. Muhammed'in haram kıldığı şeylerin ne olduğunu zikretmezken sadece şarabın haram kılındığına değinmektedir. Onun özellikle şarabı zikretmesi muhtemelen İslam'daki en bariz haramlardan biri olmasındandır. Evlilik ve ticarette şahitliğin gerektiğini belirten Yuhanna şu açıklamayı yapmaktadır:

Şahit olmadan bir kadın ile evlenemiyor, bir mülkü satın alamıyor ve sahip olamıyorsunuz. Şahit olmadan ne bir eşek ne de bir yük hayvanına sahip olamıyorsunuz. Şahit olmadan ne bir kadın ne de bir eşeğe sahip olamıyorsunuz. ${ }^{99}$

\footnotetext{
John of Damascus, On Heresies, 159.

Sahas, John of Damascus, 92.

Janosik, John of Damascus, 214.

John of Damascus, On Heresies, 160.

Sahas, John of Damascus, 94; Janosik, John of Damascus, 111.

John of Damascus, On Heresies, 155.
} 
Çok eşlilik ve cariye konusuna da değinen Yuhanna ${ }^{100}$ daha önce bahsi geçen Nisâ Suresi kapsamında bunları ele almaktadır. Boşanma ve hülle101 konularında ise şu açıklamaları yapmaktadır:

O ayrıca kişinin istediği kadını boşayabileceğini, aynı şekilde istediği kadını da alabileceğini söyler... Onu kendisine alıp, onunla zina ettikten sonra ise bunu şerî bir kural haline getirdi: "Bırakın isteyen karısını boşasın ve eğer kişi onu boşadıktan sonra, ona geri dönmek isterse, bırakın başkası onunla evlensin. Çünkü başkası onunla evlenmeden onu geri almak yasal değildir. Dahası eğer bir kardeş karısını boşarsa, diğer kardeş dilerse onunla evlenebilir. ${ }^{102}$

Onun yukarıda zikredilen değerlendirmeleri bazı art niyet ve yanlışlıklar içerse de en azından o bu konulardan haberdardır.

\section{Sonuç ve Değerlendirme}

Yuhanna, İslam'a dair sadece eleştiri konusu olabilecek meselelere odaklanmışır. Bu durum onun İslam'a yaklaşım tarzının betimleyici olmaktan çok tenkit amaçlı olduğunu göstermektedir. Pek çok din ve mezhebe eleştiriler yönelten Yuhanna'nın İslam'a yönelik eleştirileri diğer mezhep ve dinlere nazaran daha fazladır. Bu durum onun İslam'1 Hıristiyanlığa daha ciddi bir rakip olarak gördüğünü düşündürmektedir. Nitekim İslam toplumunda yaşayan ve İslam'1 sapkın bir gelenek olarak niteleyen Yuhanna bunu yaparken Hıristiyanlık'1 merkeze almakta ve İslam'1 onun karşısına yerleştirmektedir.

Müslümanların cahiliye ile olan bağını sürdürdüğü iddiasından hareketle Müslümanları putperest olmakla suçlayan Yuhanna'nın bu tavrını Müslüman cenahtan Hıristiyanlara yöneltilen şirk eleştirilerine karşı bir reaksiyon olarak değerlendirmek gerekir. Nitekim o Hz. Muhammed'in cahiliye Araplarını monoteizme döndürmesini olumlu karşılamaktadır.

Yuhanna Kur'an ismini zikretmese de Kur'an'dan alıntılar yapan ilk Hiristiyan teologdur. Onun nazarında Kuran ve hadis ayrımı söz konusu değildir. Faydalandığı bilgilerden bazıları Kur'an ayeti iken diğer bazıları ise hadistir. Onun, Kur'an'ın tamamına ilk elden ve bütün olarak ulaşabilmiş

\footnotetext{
100 John of Damascus, On Heresies, 157.

101 Karısını boşayan erkeğin, tekrar eski karısı ile evlenebilmesi için kadının başka bir erkek ile evlenmesi gerektiği şeklindeki fıkhî terim. Bkz. Saffet Köse, " Hülle”, DİA, C. XVIII, s. 475-477.

102 John of Damascus, On Heresies, 157.
} 
olabileceğini söylemek zordur. Kur'an'a dair alıntıları kısmî ve muhtemelen çevresindeki Müslümanlardan duyduklarından ibarettir. Nitekim onun alıntıları eksik ve hatalar barındırmaktadır. Bu durum onun kullandığ ayetlere ikinci elden ulaşmış olabileceğini düşündürmektedir.

Hz. Muhammed'in hem şahsına hem de peygamberliğine tenkitler yönelterek onun gerçek bir peygamber olmadığını ispatlama çabası içerisine giren Yuhanna böylelikle insanların Hz. Muhammed ve onun dininden uzaklaşacağını düşünmektedir. Bunu yaparken sadece kendi kaynaklarını değil Kuran gibi İslam kaynaklarını da kullanmaktadır. Ayrıca bazı rasyonel kanıtlar da sunmaya çalışmaktadır.

Yuhanna'nın İslam eleştirilerinin ön plana çıktığı İsmaîlîlerin Sapkınlı̆̆ başlıklı eseri hacim olarak küçük olmasına rağmen etkisi oldukça büyük olmuştur. Kendisinden sonra gelen pek çok Hıristiyan yazar onun eleştirilerini sürdürmüştür. Müslümanlar ve $\mathrm{Hz}$. Muhammed için çizilen putperest, sapkın ve şehvetperest imajı, onun kendisinden sonra gelenlere bıraktığı negatif bir İslam imajıdır. İslam ve Müslümanlara bu menfî bakış açısına kaynaklık yapan eseri bu açıdan önem arzetmekte ve Hıristiyanların en çok ilgilendiği ve çalışma yaptığı eserlerden biri olmaktadır.

\section{Kaynakça}

Ali, Cevad. el-Mufassal fî Târîhi'l-Arabî Kable'l-İslâm. Camiatu Bağdad, 1993.

Altaner, Berthold. Patrology. çev. Hilda C. Graef. New York, 1961.

Andrae, Tor. Mohammed: The Man and His Faith. Routledge, 2008.

Berkey, Jonathan P.. The Formation of Islam: Religion and Society in the Near East, 600- 1800. Cambridge University Press, 2003.

Chase, Frederic H. (çev.). Saint John of Damascus Writings. The Father of The Church. ed. Roy Joseph Deferrari. New York, 1958. XXXVII.

Demirci, Kürşat. "Deccal”. DİA, https://islamansiklopedisi.org.tr/deccal\#1 (Erişim tarihi, 19.10.2019).

Drijvers, H. J. W.. Cults and Beliefs at Edessa. Leiden: Brill Publisher, 1980.

El-Âlûsî, Seyyid Mahmud Şükri. Bulûğu'l-Ereb fî Ma'rifeti Ahvâli'l-Arab. Mısır: elMektebetu'1 Ehliyye, 1924.

El-Mes'udi. et-Tenbîh ve'1-İşrâf. Kahire: el-Mektebetu't-Tarihiyye, 1938.

Eutychius. Annales, Scriptores Arabici Textus Series Tertia-Tomus VII, ed. ve çev. Louis Cheikho. Beirut, 1909.

Fayda, Mustafa: "eş-Şürûtü'l-Ömeriyye”. DİA, https://islamansiklopedisi.org.tr/essurutul-omeriyye (Erişim tarihi, 19.10.2019).

Göregen, Mustafa. “Hıristiyan Teolojisinde Yahya Dimeşki'nin Yeri ve Önemi”. Yüksek Lisans Tezi, Marmara Üniversitesi SBE, İstanbul 1995.

Hanecioğlu, Leyla. "Yuhanna ed-Dımeşki'nin İslam ve Hıristiyanlık Arasındaki İlişkideki Yeri". Yüksek Lisans Tezi, Ankara Üniversitesi SBE, Ankara 2002. 
Harman, Ömer "Yuhannâ ed-Dimaşkî", DİA, https://islamansiklopedisi.org.tr/yuhanna-ed-dimaski (Erişim Tarihi, 19. 10. 2019).

Hitti, Philip Khuri. History of The Arabs From The Earliest Time to The Present. New York: Macmillan Education, 1970. History of Syria. New York: Macmillan Education, 1951.

Hoyland, Robert G.. Seeing Islam as Others Saw It a Survey and Evaluation of Christian, Jewish and Zoroastrian Writings on Early Islam. New Jersey: The Darwin Press, 1997.

İbnu'1-Kelbî. Kitâbu'1-Esnâm. çev. Beyza Düşüngen Bilgin. Ankara: Ankara Okulu Yayınları, 2016.

Janosik, Daniel J.. John of Damascus: First Apologist to the Muslims The Trinity and Christian Apologetics in the Early Islamic Period. Eugene: Pickwick Publications, 2016.

John of Damascus. On Heresies. Saint John of Damascus Writings. çev. Frederic H. Chase. The Father of The Church. ed. Roy Joseph Deferrari. New York, 1958. XXXVII.

Orthodox Faith. Saint John of Damascus Writings. çev. Frederic H. Chase. The Father of The Church. ed. Roy Joseph Deferrari. New York, 1958. XXXVII.

Khoury, Paul. “Jean Damascène et l'Islam”. Proche-Orient Chrétien. Paris, 1957.

Küng, Hans. Islam: Past, Present and Future. OneWorld Publications, 2007.

Louth, Andrew. Saint John of Damascene. Oxford University Press, 2002.

Meyendorff, John. Byzantine Theology Historical Trends and Doctrinal Themes. New York: Fordham University Press, 1979.

İbn İshak, Muhammed. Siyer. haz. Muhammed Hamidullah. çev. Sezai Özel. İstanbul: Akabe Yayınları, 1988.

Nasrallah, Yusuf. Mansûr b. Sercûn el-Ma'rûf bil'Kıddîs Yuhanna ed- Dımeşkî. Beyrut: Menşurat el-Mektebe el-Bulsiyye, 1991.

Nevo, Yehuda, Koren, Judith. Crossroads to Islam: The Origins of the Arab Religion and the Arab State. Amherst, 2003.

Sahas, Daniel J.. John of Damascus on Islam The "Heresy of The Ishmaelites". Leiden: Brill Publisher, 1972.

Taşpınar, İsmail. “Doğu'nun Son Kilise Babası Yuhanna ed-Dımaşki (649-749) ve İslam". Marmara Üniversitesi İlahiyat Fakültesi Dergisi, 21/2 (2001): 23-54.

Theophanes. The Chronicle. çev. Harry Turtledove. Philadelphia: University of Pennsylvania Press, 1982.

Watt, W. Montgomery. Hz. Muhammed Peygamber ve Devlet Adamı. çev. Erdem Türközü. İstanbul: İletişim Yayınları, 2015.

Wensick, Arent Jan.. A Handbook of Early Muhammadan Tradition, Alphabetically Arranged. Leiden: Brill Publisher, 1927.

Yavuz, Şevket: “Uzza”. DİA, https://islamansiklopedisi.org.tr/uzza (Erişim tarihi 19.10.2019). 
Doi: 10.34247/artukluakademi.692084 | Araştırma Makalesi

\section{Recep Aydoğmuş}

\section{Christian Arab John of Damascus's Critique of Islam}

Citation/@: Aydoğmuş, Recep, Christian Arab John of Damascus's Critique of Islam, Artuklu Akademi, 2020/7 (1),147-176.

\section{Extended Abstract}

With the Muslim conquest of the cities where the Christian subjects lived, the process of Islamisation of these cities started. This process mostly was met negatively by Christian clergy of its time. The Christian theologians and clergymen criticised and opened discussions towards Islam in the order to prevent any convertion to the new relgion and to revert those who chose to be Muslim to their previous religion. These criticisms, which previously were only verbally, have been expressed in writing over time. One of the Christian theologians who wrote their criticism about Islam is John of Damascus.

John of Damascus, who was accepted as the last church father and church doctor, served in the financial bureaucracy during the Umayyad period and had the opportunity to get to know the Muslims closely. After leaving his duty in the bureaucracy, he entered the monastery of Mar Saba, lived an ascetic life, wrote theological works defending Christianity. Also, John of Damascus denied many religions and denominations, especially Islam. One of the most important works of John of Damascus is called The Fount of Knowledge. The second part in this work, which consists of three parts, is devoted to sects and religions- where he describes heretic sects and religions.

One of the religions that John described as heretic is Islam. In On Heresies, the second part of The Fount of Knowledge, he put forward his views on Islam under the heading The Heresy of the Ishmaelites. Living in a Muslim community, John used Islam's own resources to criticize Islam and Muslims. One of the first sources he referred to is the Qur'an. He cited some verses from the Qur'an to support his views. However, there are some mistakes and shortcomings in the verses he quotes. This demonstrates that he did not receive the Qur'a-nic verses firsthand. He also benefited from the hadiths of Muhammad and some other Byzantine sources.

When the work of John is examined, it will be seen that in this short work he touches many issues related to Islam. One of the issues that he touches on is belief in tawh $\mathrm{d}$. He shows that he understands the essence of Islam by expressing that Muslims believe in one creator. His statements on this matter evoke the Sura of al-Ikhla`s.

John also includes some claims and information about the prophet Muhammad. One of his main aims is to prove that Muhammad is not a prophet. Because, if he could justify this claim, he would have revealed that Islam is a false religion. Therefore, he tries to reveal that Muhammad cannot be a prophet by basing his claim both on the Qur'ann and the Bible. 
Another of his claims regarding Muhammad is that he is a dishonest person and liar, he made up the religion of Islam, learned the Qur'an from someone else and deceived people. He argues that an Ariusian priest taught him the Qur'ann and he received the information in the Qur'ann from the Old and New Testaments. Another claim about Muhammad is that he is someone who is fond of lust. He is trying to draw a lustful, woman-loving image of Muhammad through the story Zayd. Describing Islam as a heretic movement, John also introduces Muslims as paginates. The main argument on which he bases his claim is the respect that the Muslims showing to the black stone (hajar al-aswad).

Apart from the above-mentioned issues, John also has knowledge of some secondary issues. He addresses both the halal and harams in Islam and some other issues related to Islamic law. Among them are titles such as witnessing in marriage and trade, polygamy and concubine, divorce and fake marriage ( $k h u l)$.

John also shows that he knew about the pre-Islamic period. He describes Arabs as Ishmaelites, Hagerians and Sarasins. He states that they were pagan in the period of jahiliyyah. On the other hand, he adds some new claims. He states that the Arabs of jahiliyyah worship Aphrodite. He states that Muhammad turned them into monotheism.

The Heresy of the Ishmaelites which contains John's thoughts on Islam, is one of the earliest and most important works in the history of Christian-Muslim polemics. Although it was short in volume, its effect was great and the claims made in this work were continued to be discussed by the following Christians. 